\title{
Assessing the Removal of Turbidity and Coliform Transport through Canal-Bed Sediment at Lab-Scale: Column Experiments
}

\author{
IMDAD ALI KANDHAR*, GHOUS BUX KHASKHELI**, ABDUL RAZAQUE SAHITO*, \\ AND RASOOL BUX MAHAR*** \\ RECEIVED ON 09.11.2016 ACCEPTED ON 29.05.2017
}

\begin{abstract}
This study was conducted at lab scale to determine the performance of the canal-bed for the removal of turbidity and microorganisms TC (Total Coliforms) from surface water. The canal-bed sediments were collected and analyzed for the characteristics of sediments for grain size distribution, hydraulic conductivity and the POM (Particulate Organic Matter) percent. Canal-bed sediments were containing fine particles $<0.075 \mathrm{~mm}$ in the range of $40-58 \%$, with hydraulic conductivity averaged $7 \mathrm{ft} / \mathrm{day}$, and the POM $2.75 \%$. The water samples collected from the canal-water have shown average POM $3.6 \%$. Theremoval-reduction in turbidity and TC were determined through the column experiments on the canal-bed sediments. Three columns were prepared at lab-scale by using prepared canal-bed sediment as a filter-bed in the columns for the filtration of raw water samples. Fine particles of the canal-bed grain size $D_{10} 0.2$ and $D_{10} 0.1 \mathrm{~mm}$ were selected for the filter-bed formation. The prepared concentrated and diluted influent water samples containing turbidity and TC were passed through the washed filter-bed into the columns for 8-weeks filter run. The frequency of sampling and analysis were followedafter the interval of one-week run, the influent (raw water) and effluent (filtered) water samples were collected and analyzed for the turbidity and TC concentrations. The performance of the grain size $D_{10} 0.1 \mathrm{~mm}$ have shown $95-99.95 \%$ reduction in turbidity and TC compared to the larger grain size having $\mathrm{D}_{10} \mathbf{0 . 2} \mathrm{mm}$ particles.
\end{abstract}

Key Words: Ground Water, Surface Water, Grain Size Distribution, Hydraulic Conductivity, Particulate Organic Matter, Turbidity, Total Coliforms.

\section{INTRODUCTION}

W $N_{\text {cos }}^{2}$ ater is an essential element for our survival. Deterioration in water quality and contamination of lakes, rivers and groundwater aquifers has resulted in increased waterborne diseases and other health impacts. The people of developing countries do not have an access to safe drinking water and sanitation [1]. In Sindh 95\% of shallow groundwater supplies are bacteriological contaminated [2]. Less than 30\% of groundwater of Sindh province is fresh; much of the province is underlain by

Corresponding Author (E-Mail: ar.sahito@faculty.muet.edu.pk)

* Institute of Environmental Engineering \& Management, Mehran University of Engineering \& Technology, Jamshoro.

** Department of Civil Engineering, Mehran University of Engineering \& Technology, Jamshoro.

*** US-Pakistan Centre for Advanced Studies in Water, Mehran University of Engineering \& Technology, Jamshoro.

Mehran University Research Journal of Engineering \& Technology, Volume 36, No. 4, October, 2017 [p-ISSN: 0254-7821, e-ISSN: 2413-7219] 
highly brackish water [3]. It is estimated that 40 million people depend on irrigation water for their domestic usein areas where the groundwater is saline in nature. It is also reported that about $24 \%$ of the rural population gets water from irrigation canals or dug wells [3]. Groundwater serves half of the global population as the primary source for drinking water with little or no additional treatment $[4,5,6]$. Surface water sources with microbial contamination is frequently treated, to remove turbidity and pathogens through conventional methods of water treatment using the filter-bed of porous media, such as, slow sand filtration, and the disinfection process of drinking water treatment. Surface water is also being treated through the natural process of treatment-filtration such as riverbank filtration $[7,8]$.

A major group of water pollutants are microorganisms, and physiochemical compounds. The microorganisms (Pathogens) are diseases causing bacteria, which includes giardia, lamblia, viruses and parasites, organic compounds include naturally occurring organic matter (dissolved and particulate) and the inorganic contaminants include health related toxic metals and nitrates [4]. The microorganisms (pathogens) have frequently been found to occur in shallow groundwater wells $[4,9]$. They may be inactivated during the passage of surface water infiltration through porous media towards the aquifer.Various studies have been conducted on the transport of the microorganisms at lab-scale by using the porous media as a filter-bed. The variable filter-bed design parameters and different porosity of the filter-media are applied to isolate the influence of specific processes and factors [10]. Scott et. al. [11] have discussed the detailed studies on the fate and transport of the pathogens in the subsurface environment these studies have been conducted largely at the laboratory scale.

According to Kanerick and Michail [12], the removal of organic compounds, nitrogen, phosphorus, suspended solids, bacteria, and viruses through a soil-infiltration treatment system is achieved through infiltration, percolation, sorption, chemical reaction, biotransformation, die-off, and predation processes during infiltration of surface water. Phosphorus removal in soil-media is influenced by the properties of the soilmedia, mainly sorption and precipitation [13]. Organic matter is predominantly removed through adsorption and biodegradation. Degradation of oxidizable organic substances is facilitated by microbial metabolism [14]. Coliform bacteria and E.coli are used as indicator bacteria to detect fecal contamination [15]. Reductions of pathogens in water treatment play an important role in minimization of public health risks [16]. The major factors influenced in the performance of soil-media are the raw water quality and the soil properties, during the infiltration process of the water pollutants through the porous media for the attenuation or removal of the water pollutants [17].

Keeping the idea from the literature for the removal of physical and biological contaminants from water through porous media, soil-packed column experiments were conducted. During this study the effectiveness of the canal-bed sediments for the removal-reduction of TC and turbidity was examined at different intervals of sampling and analysis of raw water and treated water (filtered water) during the column experiments. This study was conducted to evaluate the performance of the canal-bed sediments regarding the removal of bacteria TC and turbidity of the contaminated water and to determine the effect of influent water quality, grain size and the flow-rate (detention-time) on the performance of filter-bed during the column experiments. The aim of this piece of work is to analyze the removal efficiency of TC by the sand available in the canal bed under local geological settings of the study area. The main reason for choosing TC as an indicator organism in this study is because, it is easy to detect and enumerate in water and are representative enough for determining fecal contamination of drinking water. By monitoring TC bacteria, the increase or decrease of many pathogenic bacteria can be estimated. 


\section{METHODOLOGY}

\subsection{Canal-Bed and Canal-Water Sediments Sampling and Analysis}

Three canals are off-taking from the upstream Kotri barrage, Hyderabad and are used for the various water supply schemes, these canals are flowing across the Hyderabad city area. The canal-bed and canal-water samples were collected from the Pinyari-Canal at by-pass bridges Hyderabad as shown in Fig. 1.

\subsubsection{Sediments Sampling}

The disturb soil (sediment) core composite samples were taken from the canal-bed and six grab sample were collected from the surface of the canal-bed at the depth of $6 \mathrm{~cm}$. Then 6-grab samples were mixed thoroughly in a bucket to make one composite sample of each location as shown in Fig. 1. Then the composite samples of canal-bed sediments were labeled and transferred in the polyethylene bags for further laboratory analysis.

\subsubsection{Method of Grain Size Distribution Analysis}

The physical analysis of the soil samples, the GSD (Grain Size Distribution) was carried out by applying ASTM methods of sieving [18]. The stack of the sieves was selected for the medium to fine sand particles such as $4.75,2.0,0.425,0.15,0.075 \mathrm{~mm}$ and $<0.075 \mathrm{~mm}$, the percent passing dry-weight of the sediments through each sieve of the stack was calculated.

\subsubsection{Method of Hydraulic Conductivity Estimation}

The hydraulic conductivity of the canal-bed sediments was estimated by using Equation (1) [19].

$\mathrm{K}=\mathrm{C} \cdot \mathrm{D}^{2}{ }_{10}$
Where $\mathrm{K}$ is the hydraulic conductivity in a ft/day, $\mathrm{C}$ is the constant and is equal to 100 , and $\mathrm{D}_{10}$ is the effective size of particles corresponding to $10 \%$ passing taken in $\mathrm{cm}$.

\subsubsection{Particulate Organic Matter Sampling \& Preparation}

The known quantity of composite samples of canal-bed sediments were passed through the sieve size of $0.075 \mathrm{~mm}$ during washing of the sediments, the filtrate water plus passed fine particles of the clay and silt were collected in the Imhoff-cone for the plain sedimentation of the suspended fine particles in washed water. The Imhoffcone containing fine sediments and water was kept undisturbed for 24 hours at room temperature; the settled residue was carefully drained from the cone into a glass beaker. The settled residue containing the clear water over the settled fine sediments were siphoned carefully from the Imhoff-cone passed through $0.45 \mu \mathrm{m}$ filter. Then the beaker and filter was oven dried at $105^{\circ} \mathrm{C}$ for one hour, and then cooled at room temperature. The dry sediment samples were taken for the POM, weight percent analysis, by using the dichromate method dichromate method 8097 for soil analysis at 610nm wavelength through DR/2000 Spectrophotometer [HACH-USA]. POM was measured by an approximate relationship with organic carbon. Organic carbon is oxidized to carbon dioxide in the

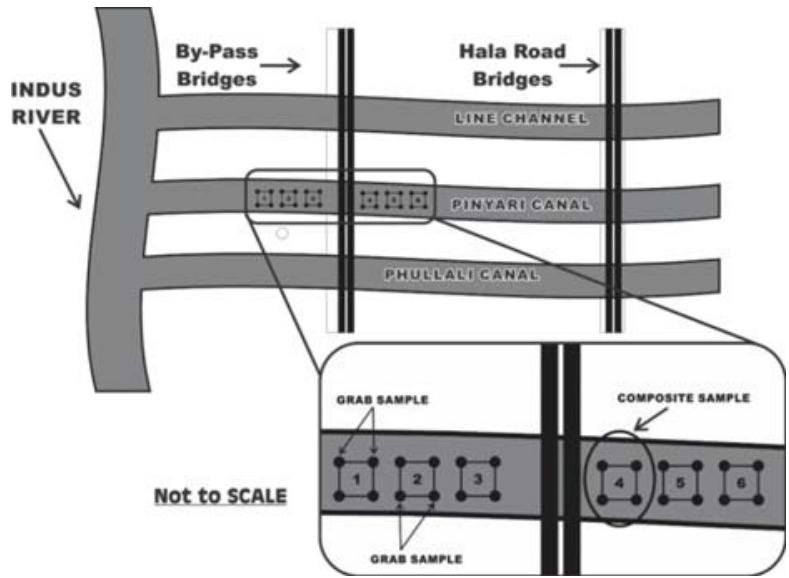

FIG. 1. CANAL-BED AND CANAL-WATER SAMPLING POINTS AT BY-PASS BRIDGES

Mehran University Research Journal of Engineering \& Technology, Volume 36, No. 4, October, 2017 [p-ISSN: 0254-7821, e-ISSN: 2413-7219] 
dichromate method with a parallel reduction of hexavalent chromium $\left(\mathrm{Cr}^{+6}\right)$ to trivalent chromium $\left(\mathrm{Cr}^{+3}\right)$ and an accompanying color change from orange to green. The intensity of the green color is proportional th the trivalent chromium concentration which is related to the organic matter content in the soil.

Similarly, the turbid water composite samples were collected from the Pinyari canal at the by-pass bridges Hyderabad during different month of sampling and analysis for POM\%in the canal water. The canal water samples were prepared by using the $0.45 \mu \mathrm{m}$ filter for the suspended sediment collection. The known volume of the canal water was passed through the filter and then the filter was placed into the oven for $105^{\circ} \mathrm{C}$ for 24 hours. The dry weight of the sediments was taken for the analysis of the POM\% in water by using the dichromate method [HACH-US-EPA 8097] for soil analysis through spectrophotometer.

\subsubsection{Sediments Collection and Preparation for Filter-Bed in Columns}

The sediments were collected and passed through sieve ASTM No. $200(0.075 \mathrm{~mm})$, and then the tape water was used to wash the sediments, during the washing fine particles (clay-silt) were passed-removed through the sieve. Furthermore, washed sediments was soaked in distilled water after stirring the sample was kept for 24 hours in water to remove the possible soluble salts from the sediments, after that washed soil-sediments was dried in the oven at $105^{\circ} \mathrm{C}$ for 24 hours.

The washed and dried canal-bed sediments were sieved and analyzed to take the required effectivesize of particles as $\left(\mathrm{D}_{10} 0.2\right.$, and $\left.\mathrm{D}_{10} 0.1 \mathrm{~mm}\right)$ of the sediments. Three columns were filled, as column $\mathrm{C}-1$ with $\left(\mathrm{D}_{10} 0.2 \mathrm{~mm}\right)$ particle size and column C-2 and C-3 with ( $\left.\mathrm{D}_{10} 0.1 \mathrm{~mm}\right)$ particle size of the canal-bed sediments. During the addition of sediments into the columns, columns were tapered to fill the gaps between the particles. For the removal of air from the voids of soil grains back flow of water to upward moving was applied to fully saturate the sediments filled in the columns. The prepared filter-bed in the columns was further washed by passing 5-6 liters of distilled water, before the column experiments.

The $\mathrm{D}_{10}$ size of the grains was taken to prepare the filter bed in the columns to know the performance of the filter beds by changing the grain size and the influent water quality, generally the raw water (surface water) is being treated through slow sand filters where the effective grain size of the filter bed is required to treat the pollute water. In this study the grain size of the sediments was selected as it was found during the analysis of the canal-bed sediments.

\subsubsection{Columns Specifications and Operational Parameters}

In order to analyze the effect of the removal of turbidity and TC, the laboratory scale columns were designed and fabricated as shown in Fig. 2. The length and thickness of the filter-bed in the columns acts a major role in the water infiltration process, which depends on the covered area of filter-bed whereas water infiltrate through porous media. The columns were exposed to atmospheric air at the inlet of the columns to maintain aerobic conditions during the experimental work. Also the influent water was containing dissolved oxygen and TC during the infiltration process of water through filterbed in the columns. Whereas, the attenuation process of physical, chemical and biological pollutants occurs within the porous media. The attenuation of water pollutants, such as adsorption of microorganisms, oxidation/reductions of chemical compounds and the screening of suspended particles provides the naturally treated water [US-EPA]. The water pollutants (physical, chemical and biological) are adsorbed, oxidized, decomposed, reduce or removed from the influent water. The thickness of filter-bed with a diameter of $63 \mathrm{~mm}$, 
depth $200 \mathrm{~mm}$ and the length $300 \mathrm{~mm}$ of the columns were kept during this study, including the other designed parameters of the laboratory scale columns are given in Table 1. The prepared canal water samples as influent containing the TC and the turbidity was applied to pass through the columns filter-bed. The parameters such as

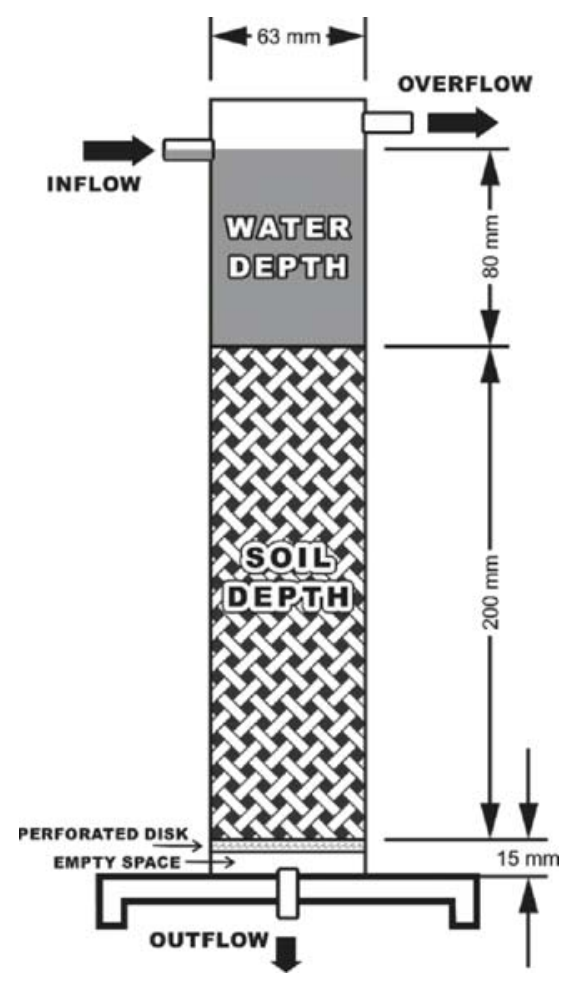

FIG. 2. LABORATORY SCALE COLUMN DESIGN water level over the filter-bed and flow rate at the inlet and outlet was maintained initially around 2-4ml/min for first week run to saturate the filter-bed. The outlet flow was controlled through clipper/valve to increase the retention time of the influent water within the filter-bed in the columns. The flow-rate was measured by using the $10 \mathrm{ml}$ measuring cylinder and the stop watch; the readings were recorded as $\mathrm{ml} / \mathrm{min}$, flow-rate of the effluent water. The samples were taken from the inlet and outlet of the columns for the turbidity and TC analysis.

Total three columns were fabricated with same specifications. Moreover, the operational parameters for column experiments are summarized in Table 2.

TABLE 1. DESIGN PARAMETERS OF LABORATORY SCALE COLUMNS

\begin{tabular}{|c|c|}
\hline Parameters & Dimensions \\
\hline Diameter of Column, (mm) & 63 \\
\hline Length of Column, (mm) & 300 \\
\hline Water level (over-flow) of column, (mm) & 10 \\
\hline Water level over soil in column, (mm) & 80 \\
\hline Depth of soil in column, (mm) & 200 \\
\hline Under drain level in column, (mm) & 10 \\
\hline Dry density of soil (g/cm3) & $1.9-2.0$ \\
\hline Porosity (\%) of soil & $31-32$ \\
\hline Grading of soil & Silty Sand \\
\hline
\end{tabular}

TABLE 2. OPERATIONAL PARAMETERS FOR COLUMN EXPERIMENTS

\begin{tabular}{|c|c|c|c|}
\hline Parameter & Column (C-1) & Column (C-2) & Column (C-3) \\
\hline EGS (D100.2 and 0.1mm) & $0.2 \mathrm{~mm}$ & $0.1 \mathrm{~mm}$ & $0.1 \mathrm{~mm}$ \\
\hline Influent Water & Raw + Canal Water & Canal Water & $1.4-1.9 \mathrm{ml} / \mathrm{min}(1.643)$ \\
\hline Flow Rate at Outlet (Average) & $1.7-2.1 \mathrm{ml} / \mathrm{min}(1.887)$ & $0.5-1.2 \mathrm{ml} / \mathrm{min}(0.825)$ & $0.4-1.88$ \\
\hline Average Turbidity & $90-150 \mathrm{NTU}$ & $1.5-31.3 \mathrm{NTU}$ & $2.4 \mathrm{mg} / \mathrm{L}$ \\
\hline Nitrate-Nitrogen (N-NO3) & $10.2 \mathrm{mg} / \mathrm{L}$ & $6.7 \mathrm{mg} / \mathrm{L}$ & $1 \mathrm{mg} / \mathrm{L}$ \\
\hline Phosphorous-Phosphate (PO4) & $5 \mathrm{mg} / \mathrm{L}$ & $3 \mathrm{mg} / \mathrm{L}$ & $18-27$ \\
\hline Total Coliforms (CFU/100ml) & $200-250$ & $108-120$ & Per Week \\
\hline Sampling/Analysis Interval & Per Week & Per Week & $8 \mathrm{Weeks}$ \\
\hline Column-Run Period (Weeks) & 8 Weeks & 8 Weeks & \\
\hline
\end{tabular}

Mehran University Research Journal of Engineering \& Technology, Volume 36, No. 4, October, 2017 [p-ISSN: 0254-7821, e-ISSN: 2413-7219] 


\subsection{Water Sampling and Analysis}

\subsubsection{Canal Water Sampling}

The canal water was used at each attempt of the sampling and analysis as influent water (raw water) during the column experiments. The prewashed containers were used for the collection of raw water from the canal. The canal water samples were taken from the by-pass bridges manually (Fig. 1), by inserting the glass bottle into the canal at the depth of three feet below the surface water level.

\subsubsection{Raw Water (Influent) Preparation (Dilutions) for Column Experiments}

The canal water was used to prepare the three different concentrations of the influent water for the column experiments. For the column C-1 influent water was prepared by adding the $10 \mathrm{ml}$ of domestic wastewater into the one liter of canal water. The canal water without any dilution or concentration was used for the column C-2 and third influent water sample was prepared through dilution, 25\% Canal water $+75 \%$ Distilled water for column C-3. The three different concentrations of the influent water was prepared to know the treatment efficiency of the filter bed prepared for the water treatment, by using the variable water quality characteristics and their impact on filter-bed performance under given conditions.

\subsection{Methods of Water Samples Analysis}

The US-EPA methods for the analysis of water quality parameters were used in this study and are summarized in Table 3, except TC. The US-EPAmethods for water and wastewater analysis [20] were applied by using DR/2000 Spectrophotometer (HACH-USA). The spectrophotometer was calibrated for each following water quality parameter before taking the reading of the water samples. TC were analyzed by using the MFC (Membrane Filtration Count) techniquesthe growth of the TC were developed by using the m-Endo Agar (medium) for the colony forming units per volume filtered through the pre sterilized Millipore filtration assembly. The $100 \mathrm{ml}$ volume of the influent (raw water) and the effluent (filtered water) samples were passed through the membrane-filter pore size $0.45 \mu \mathrm{m}$. The triplicates of each sample were prepared, and then the filters were placed in the Petri dishes containing the m-Endo Agar for the incubation into the preset incubator at temperature $35^{\circ} \mathrm{C}$ for $24 \pm 01$ hours. The colony forming units were counted by using the magnifying glass in each triplicate Petri dish of the same sample [21], the average results of the triplicate readings of the colony forming units were calculated.

\subsection{Duration of Column-Experiments}

The eight attempts of the sampling and analysis from the inlet and outlet of the columns were carried out to determine the TC and turbidity concentration in the

TABLE 3. WATER QUALITY PARAMETERS AND ANALYSIS METHODS

\begin{tabular}{|c|c|c|}
\hline Water Quality Parameter & Detection Method & US-EPA (Method No.) \\
\hline $\mathrm{pH}$ & $\mathrm{pH}-$ Meter & (Lovibond) \\
\hline Turbidity (NTU) & Turbidity-Meter & (HACHbond) \\
\hline Particulate Organic Matter (POM) & Dichromate Method & (HACH8038) \\
\hline Ammonia (NH3) & Nessler Method & (HACH8039) \\
\hline Nitrate (NO3) & Cadmium Reduction Method & (HACH8048) \\
\hline Phosphate (PO4) & Ascorbic Acid Method & \\
\hline
\end{tabular}

Mehran University Research Journal of Engineering \& Technology, Volume 36, No. 4, October, 2017 [p-ISSN: 0254-7821, e-ISSN: 2413-7219] 
influent and effluent water samples during the column experiments. Each attempt was at the interval of one-week process. Whereas, the percent removal and the log reduction value of the TC was calculated at the end of experimental work. During the initial run of the filter flowrate of effluent water was maintained approximately 5$6 \mathrm{ml} / \mathrm{min}$. The total volume of the influent (raw water) was 28 liters which was passed through the filter-bed. The columns were not fully blocked during the 8 weeks of experimental work, and do not require back washing process for the reclamation of the filter bed.

\section{RESULTS AND DISCUSSION}

\subsection{Characteristics of Canal-Bed Sediments}

\subsubsection{Canal-Bed Grain Size Distribution}

The GSD of canal-bed sediments is shown in Fig. 3. The upper layer of the canal-bed from $0-6 \mathrm{~cm}$ containing average $32.86 \%$ of the fine particle size ranged from 2$72 \%(0.075 \mathrm{~mm})$. The particles $<0.075 \mathrm{~mm}$ were averaging 40-58\% passing through ASTM No. 200 sieve, indicates the fine sand and silt deposits over the canal-bed, the percentage of the grain is shown in Fig. 4. The layer of fine grained sediments is considered to be the site of the improvements in water quality that occur at bank filtration sites [22]. Physical filtering and adsorption of contaminants onto grain surfaces, where microbial and chemical transformation occur in the sediment layer [15]. The contaminants of surface water reduced due to the physical filtering, microbial degradation, ion-exchange, precipitation and sorption process through soil-sediments to the groundwater [23]. The fine sediments act as a barrier for the turbid particles and the microorganisms.

On the other hand, the higher concentrations of fine particles reduce the hydraulic conductivity of filter-bed [24]. Due to the clogging of the canal-bed the recharge of aquifer decreases adjacent to the canals. Clogging of the filter-bed decreases the hydraulic conductivity of the riverbed [25]. Low hydraulics of the soil-media increases

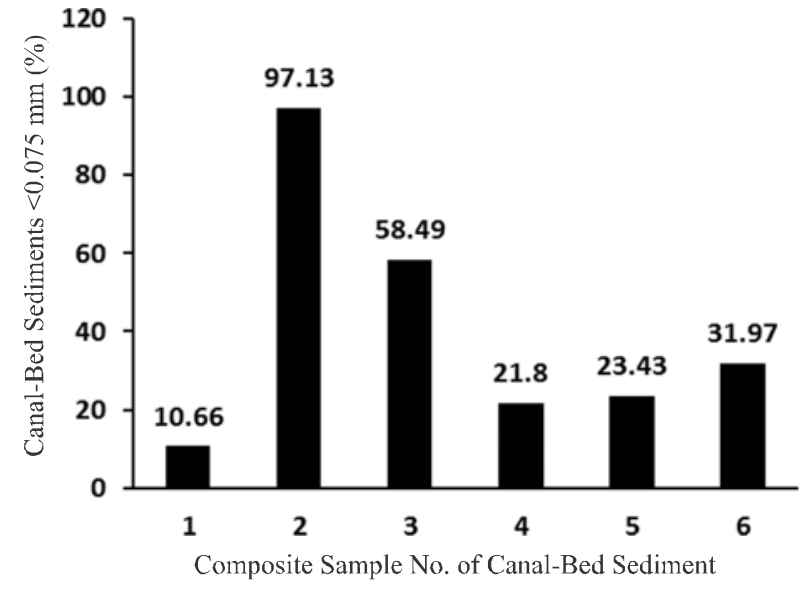

FIG. 4. CANAL-BED SEDIMENTS <0.075MM GRAIN SIZE

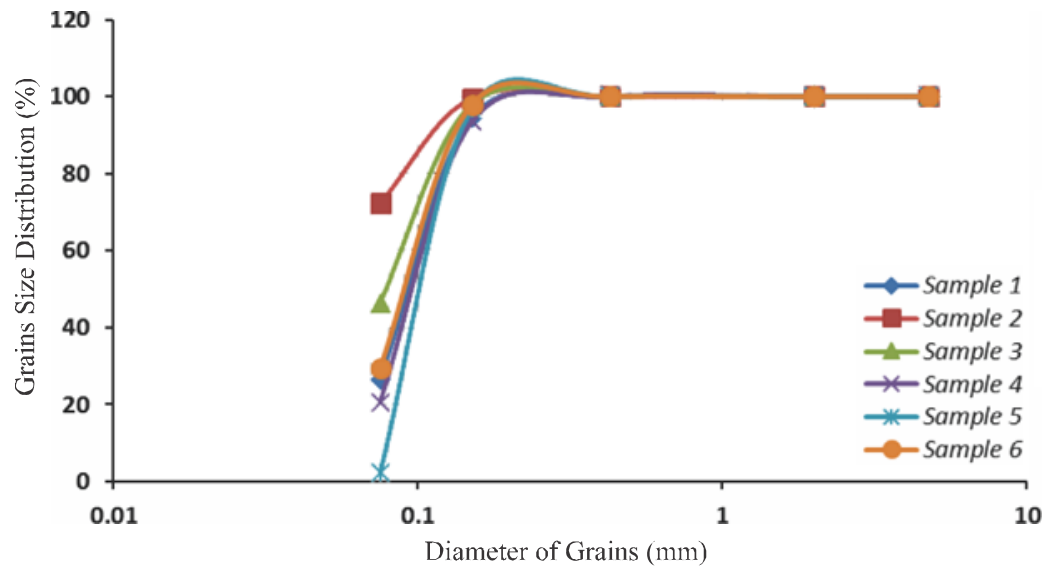

FIG. 3. GRAIN SIZE DISTRIBUTION OF CANAL-BED SEDIMENTS AT BY-PASS BRIDGES HYDERABAD

Mehran University Research Journal of Engineering \& Technology, Volume 36, No. 4, October, 2017 [p-ISSN: 0254-7821, e-ISSN: 2413-7219] 
the detention time for the water pollutants within the subsurface environment, which results the attenuation of the physical, chemical and biological pollutants [23]. The clogging of the canal-bed (riverbed) is a term used to describe a general decrease in hydraulic conductivity of the substrate at the river-ground water interface. Clogging has been explained by various causes, such as physical, chemical and biological clogging of the riverbed. The clogging of the riverbed may be scrapped during the high flow of the river water that removes the clogged layer of the riverbed [24].

\subsubsection{Canal-Bed Hydraulic Conductivity}

The average Hydraulic Conductivity value of Canal-Bed composite samples is shown in Fig. 5. As per the results, the hydraulic conductivity was ranging from 1.15-10.38 $\mathrm{ft} /$ day, with average hydraulic conductivity $7 \mathrm{ft} /$ day. Moreover, the average fine particles of clay, sand, and silt $(<0.075 \mathrm{~mm})$ was $10-70 \%$.

\subsubsection{POM of Canal-Bed Sediments}

POM is also referred as non-dissolved organic carbon, the fraction of organic matter retained on $0.45 \mu \mathrm{m}$ filter. The average POM\% dry weight $2.25 \%$ ranged from 1.96 $2.41 \%$ was calculated in the canal-bed composite soil samples Fig. 6. This indicates the sufficient percentage of the organic matter at the site for the microbial degradation process during the infiltration of surface water to the aquifer. Whereas, the natural organic matter provides the favorable conditions for the growth of the microorganisms that is utilized as a food for their survival within the subsurface environment, mainly in the presence of the DO (Dissolved Oxygen) in source water under aerobic conditions.

\subsubsection{POM of Canal-Water Sediments}

Canal-water containing POM percentage in the range from minimum $0.32 \%$ in the month of June and maximum $10.32 \%$ in September. The results of six months June to November sampling and analysis average concentration 3.6\%POM in canal water wasrecorded Fig. 7. The river-canal water is the main source of the various water supply schemes in the Hyderabad city, this water is treated through conventional treatment methods such as slow sand filtration. Water source containing POM has an adverse impact on the water treatment facilities, where the particulate matter becomes deposited over the filter-bed reduces the filtration rate of the filter-beds. Besides this, the organic matter has been shown to produce disinfection by-products such as THMs (Trihalomethanes) during the chlorination process of

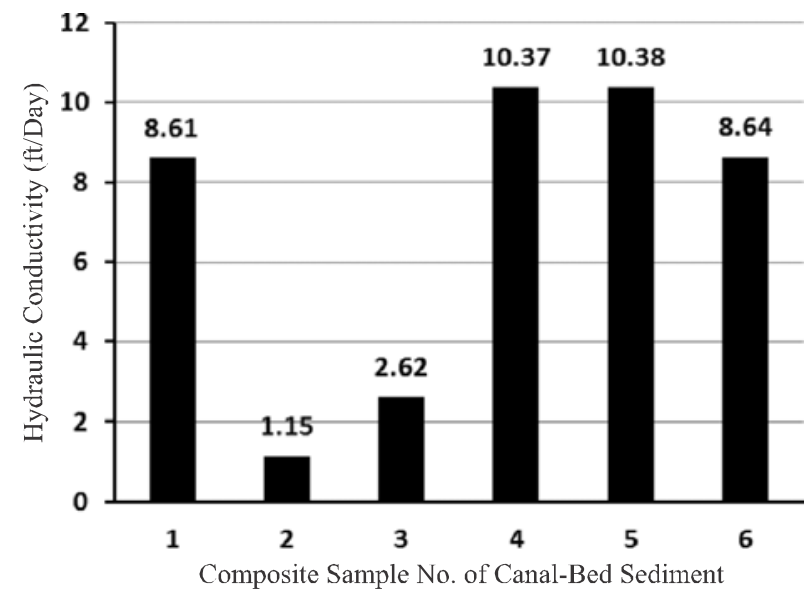

FIG. 5. AVERAGE HYDRAULIC CONDUCTIVITY VALUE OF CANAL-BED COMPOSITE SAMPLES

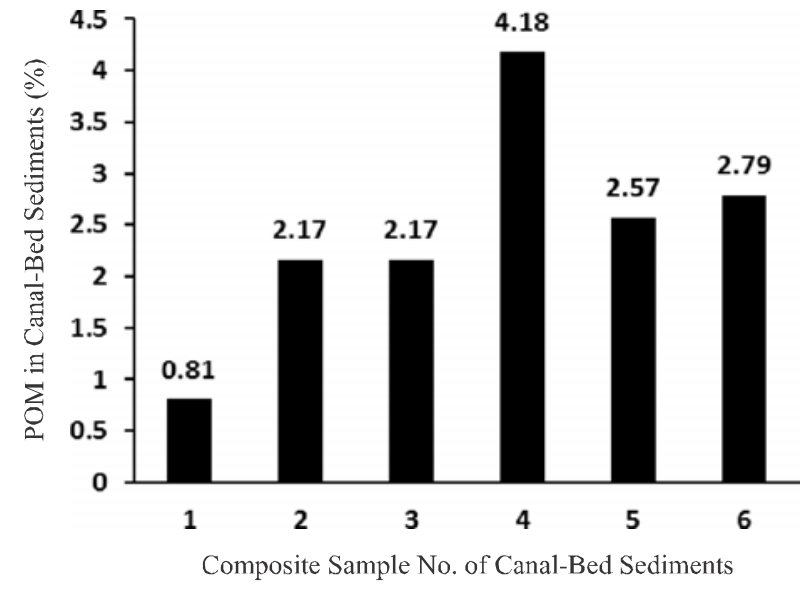

FIG. 6. PARTICULATE ORGANIC MATTERIN CANAL-BED SEDIMENTS

Mehran University Research Journal of Engineering \& Technology, Volume 36, No. 4, October, 2017 [p-ISSN: 0254-7821, e-ISSN: 2413-7219] 
water treatment [3]. Such disinfection by-products are very harmful to the health of the consumers. The maximum concentrations of POM in canal water were found during the high flow season of the river at Kotri barrage. POM may be accumulated-deposited on the canal-bed during the low flow season of the river-canals.

\subsubsection{Canal Water Quality Characteristics}

The average concentrations of canal water quality characteristics such as Turbidity, $\mathrm{pH}, \mathrm{N}-\mathrm{NH}_{3}, \mathrm{~N}-\mathrm{NO}_{3}$, $\mathrm{P}-\mathrm{PO}_{4}, \mathrm{POM}$, and $\mathrm{TC}$ were recorded during the sampling and analysis of water samples taken from the canal Table 4.

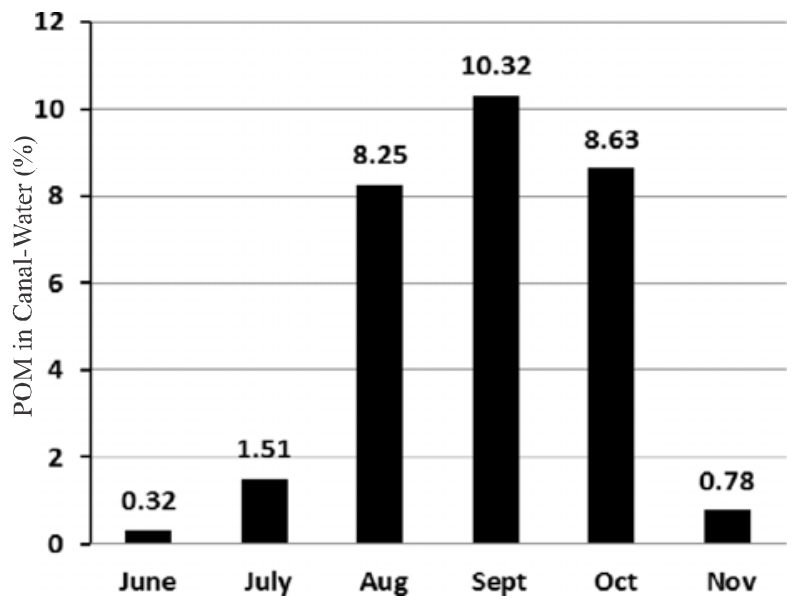

FIG. 7.PARTICULATE ORGANIC MATTERIN CANAL-WATER SAMPLES

TABLE 4. CANAL WATER QUALITY CHARACTERISTICS (AVERAGE) DURING PERIOD OF STUDY

\begin{tabular}{|c|c|c|}
\hline Parameter & Unit & Concentrations \\
\hline $\mathrm{pH}$ & value & 7.9 \\
\hline Turbidity & $\mathrm{NTU}$ & 72.8 \\
\hline Particulate Organic Matter (POM) & $\%$ & 0.32 \\
\hline Ammonia (N-NH3) & $\mathrm{mg} / \mathrm{l}$ & 0.112 \\
\hline Nitrate (N-NO3) & $\mathrm{mg} / \mathrm{l}$ & 9.5 \\
\hline Phosphate (P-PO4) & $\mathrm{mg} / \mathrm{l}$ & 0.48 \\
\hline Total Coliforms & $\mathrm{CFU} / 100 \mathrm{ml}$ & 750 \\
\hline
\end{tabular}

\subsubsection{Column Experiments}

Analyses were done in the water and soil laboratories, Institute of Environmental Engineering \& Management, and Department of Civil Engineering, Mehran University of Engineering \& Technology, Jamshoro, Pakistan. The experiments were conducted under the aerobic conditions within the columns at inlet and in the influent water.

The water level over the filter-bed was maintained through control of the flow rate at the inlet and outlet by using the clipper at the outlet delivery tube of the columns. The samples were taken at the interval of one-week filter run of each three columns. During the column experiments influent and effluent water samples were analyzed for the selected parameters. However, there was slight change in $\mathrm{pH}$ value of the raw and treated water samples so that it is not reported, the nitrate concentrations of the treated water samples were not analyzed. Results are discussed for major parameters of the study such as TC, and the turbidity. The difference in the influent and effluent water samples concentrations were calculated for the TC and turbidity parameters.

\subsubsection{Flow Rate in Columns}

Flow rate measurement is useful at both the sand selection stage and operation stage of the filter-bed development. At sand selection stage, it indicates whether the sand in the filter is of an appropriate size. At the operational stage it indicates if the filter requires maintenance. If the flow rate is too fast, the efficiency of bacterial removal may be reduced. If the flow rate is too low, there will be an insufficient amount of treated water through the filterbed. The flow rate of the influent and effluent water was maintained within the range $0.5-2.5 \mathrm{ml} / \mathrm{min}$. During the column experiments, to know the performance of the filterbed at selected flow rates for the removal of turbidity and TC.

Mehran University Research Journal of Engineering \& Technology, Volume 36, No. 4, October, 2017 [p-ISSN: 0254-7821, e-ISSN: 2413-7219] 
The retention time of the raw water pollutants within the filter-bed acts the major role to complete the process of degradation of the pollutants. The longer retention time attenuates more pollutants compared to the shorter retention time within the filter-bed. In this study retention time of the raw water was maintained through the inlet and outlet flow control valves of the columns. The turbidity and TC were analyzed for the influent and effluent water samples; the effectiveness of filter beds for the reductions in turbidity and TC was calculated at the flow rates $\mathrm{ml} / \mathrm{min}$, during the eight weeks of columns run Fig. 8.

\subsubsection{Turbidity Measurement}

Turbidity refers cloudiness of water caused by the suspension of small particles; usually silt, clay, and microorganisms. It even quantifies the degree to which the light traveling through a water column is scattered by suspended organic, inorganic or microbial contaminants. Excessive turbidity or cloudiness in drinking water is aesthetically unappealing and may also represent a health concern. Turbidity can provide food and shelter for pathogens, if not removed; turbidity can promote regrowth of pathogens leading to waterborne disease outbreaks, which have caused significant cases of gastroenteritis throughout the world [1]. Although, turbidity is not a direct indicator of health risk, numerous studies show a strong relationship between removals of turbidity and pathogens during the treatment process. Turbidity is measured in NTU (Nephlometric Turbidity Units). The WHO (World Health Organization) guideline for the non-microbial turbidity level in drinking water is set at 0-5 NTU, and for the effective disinfection process turbidity should be $<1$ NTU [1].

The turbidity removal through the column experiments is shown in Fig. 9. Turbidity removal or the reduction \% in column C-1 was minimum during the $1^{\text {st }}$ week, which was increased gradually in the range of 82-99.66\% during the 1-8 weeks, and the 8-attempts of the sampling and analysis. The concentrated influent water and larger grain size $\mathrm{D}_{10} 0.2 \mathrm{~mm}$ may have an adverse impact on the filterbed to retain turbid particles compare to the smaller grain size $\mathrm{D}_{10} 0.1 \mathrm{~mm}$ placed in the $\mathrm{C}-2$ and $\mathrm{C}-3$ columns. The column C-3 has shown maximum reduction in turbidity units since $1^{\text {st }}$ week of columns run with removal of turbidity $95.5 \%$. This shows the impact of influent water quality and the grain size on the performance of filter-bed within the columns. The column C-2 and C-3 have shown better results of the turbidity removal in the range of 92.399.95 and $95.5-99.7 \%$ respectively. The column C-1 was containing sand particle size $\mathrm{D}_{10} 0.2 \mathrm{~mm}$ as a filter-bed and column C-2, and C-3 containing sand particle size $\mathrm{D}_{10}$ $0.1 \mathrm{~mm}$. In columns experiment, overall maximum reduction in turbidity was observed during the $7^{\text {th }}$ to $8^{\text {th }}$ week.

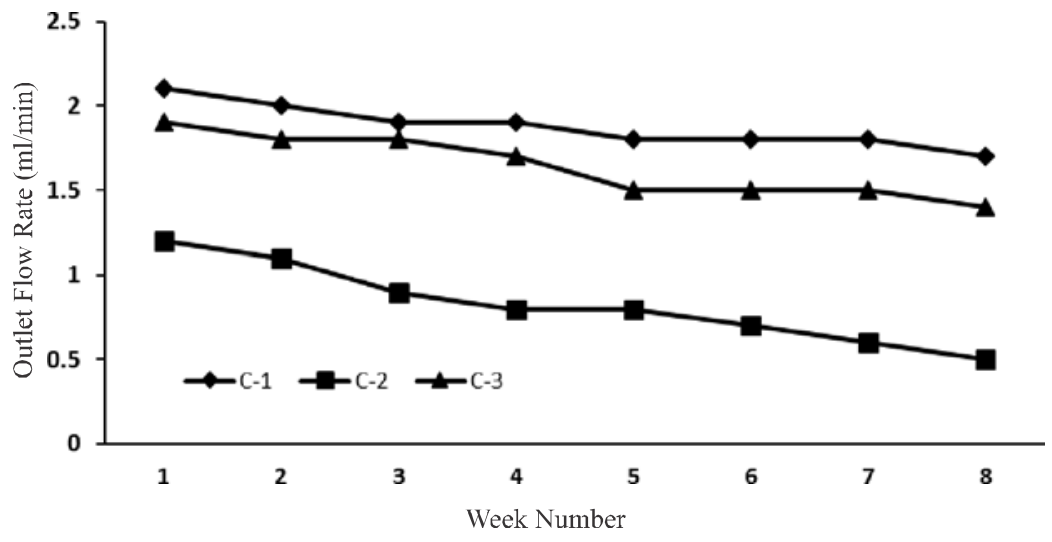

FIG. 8.OUTLET FLOW RATE OF FILTERED WATER THROUGH COLUMNS 


\subsubsection{Total Coliforms Reduction}

TC removal achieved through column experiments is shown in Fig. 10. The minimum reduction in column C-1 was observed during the fourth week of the experiment, this indicates the biofilm development was started after the $4^{\text {th }}$ week, and the maximum reduction was observed at the $8^{\text {th }}$ week of column experiment. The column C-2 has shown a better reduction compared to the $\mathrm{C}-1$, the minimum reduction was observed as (9.09\%) during the $3^{\text {rd }}$ week of the experiment, and it was increased to 75.22100\% during the 5-8 week, respectively. Column C-3 containing the same grain size and the depth of the soilsediments, where, the diluted influent water was applied shown lesser reductions in the TC comparedto the column C-2. This may be due to the biofilm development which was developed during the $6^{\text {th }}$ week in the column C-3. The minimum reduction in TC was 25\%, which was increased up to $96 \%$ during the $8^{\text {th }}$ week of column experiment.

\subsubsection{Effect of Grain Size on Performance of Filter-Bed}

The large particles having a low surface area compared to the smaller particles. Therefore, the surface area required for the attachment (adsorption) of microorganisms over the particles may be increased which enhances the reduction in the filtered water through porous media. On the other hand, the movement of microorganisms' increases due to the space between the particles of filterbed, which favors the microorganisms pass through a filter-bed and may reduce the treatment efficiency of the filter-bed due to the low adsorption of microorganisms. The filter-bed for the water filtration-treatment needs porous material, which retains the larger particles compared to the pore (voids) of the filter-bed and passes the smaller particles.

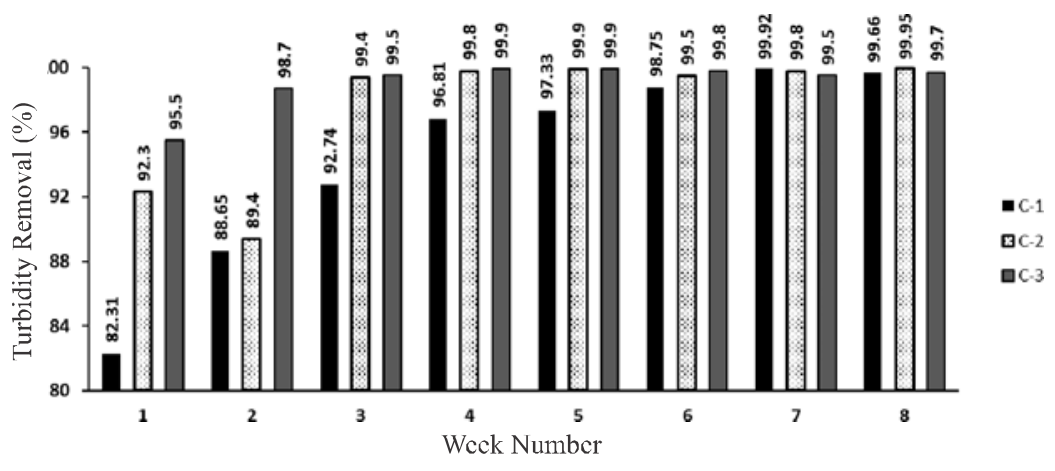

FIG. 9. TURBIDITY REMOVAL ACHIEVED THROUGH COLUMN EXPERIMENTS

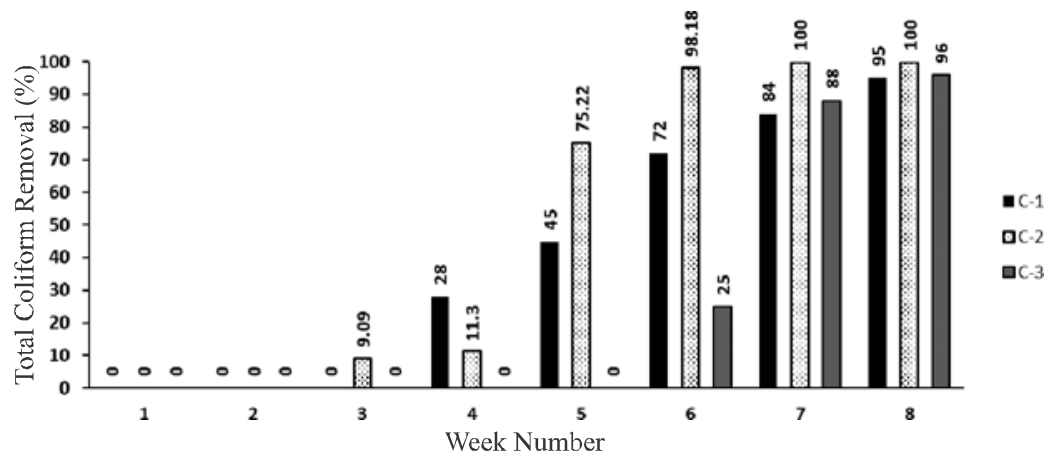

FIG. 10. TOTAL COLIFORMS REMOVAL ACHIEVED THROUGH COLUMN EXPERIMENTS

Mehran University Research Journal of Engineering \& Technology, Volume 36, No. 4, October, 2017 [p-ISSN: 0254-7821, e-ISSN: 2413-7219] 1005 
Pollute surface and ground water sources are treated through the filtration and disinfection process of water treatment for the domestic and industrial needs. Various conventional and advance techniques-methods are applied to treat the pollute water source, such as turbid and microbial contaminated water. The removal of turbidity and microorganisms (pathogens) from water is performed through a filtration process, where adsorption of microorganisms occurs over the grains of filter-bed which retains the turbidity and bacteria making, biofilm 'schmutzdecke' layer over the filter-bed the treated water become free from the turbidity and microorganisms at some extent. Furthermore, the disinfection (chlorination) process is applied to kill the microorganisms, to make it fit for drinking physically and biologically.

The results obtained during the soil-packed columns study for the removal-reduction of TC and turbidity from contaminated water, the filter-bed in the columns was prepared by using grain size $\left(\mathrm{D}_{10} 0.2\right.$ and $\left.\mathrm{D}_{10} 0.1 \mathrm{~mm}\right)$ of the sand particles. Out of three columns, two columns C2 and C-3 were containing $0.1 \mathrm{~mm}$, and C-3 was containing $0.2 \mathrm{~mm}$ grain size.

The overall performance of the columns regarding microorganisms' removal was good achieving 11-100\% removal of TC. The best performance with the consistent result was attained by the column $\mathrm{C}-2\left(\mathrm{D}_{10} 0.1 \mathrm{~mm}\right)$ sand configuration, while column C-3 with same sand configurations have shown less performance below $<100 \%$ removal of TC. The column C- $1\left(\mathrm{D}_{10} 0.2 \mathrm{~mm}\right)$ sand configurations have shown $10-95 \%$ reduction in concentration of TC Fig.10.

Ausland et. al. [26] and Langenbach et. al. [27] found out that a decrease in grain size leads to an increase in treatment efficiency. From the results obtained in this study, indicator bacteria TC seems to follow the same trend, i.e. the highest bacterial removal corresponded to the finest grain size. The difference of bacteria removal becomes evident when sand configurations are different in grain size. Stevik et. al. [28] explained that adsorption is the most important mechanism in retaining bacteria compared to straining. An increase in the sand surface area leads to an increase in adsorption spots on the sand and biofilm attached to the sand grains. The results achieved in this study showed that indeed, fine sand or smaller grain sizes present a larger sand surface area compared to coarse sand and therefore provide more adhesion or adsorption spots. Ekha et. al. [29] reported the effect of grain size distribution and grain shape on filter performance for the removal of bacteria, have concluded that the smaller grain size leads to an increase in bacterial removal.The sand size is not only the main reason of the performance of the filter bed, but other factors such as the raw water (influent) quality have also effect on the removal of the coliforms during the infiltration process.

\subsubsection{Effect of Influent Water Quality on Performance of Filter-Bed}

The lower concentration of the chemical and the low density of the bacteria have also effect on the filter-bed performance, because the biofilm layer development is necessary to retain the bacteria and the turbidity from water during infiltration. In this study the concentration of the influent water applied in the column experiments was different, the concentrated water, undiluted water and diluted water was prepared for the column C-1, C-2 and C-3, respectively as given in Table 2 . The undiluted water for column C-2 has shown better results compared to the diluted water for column C-3. The reason may be because of the biofilm layer development over the filter bed, which was started to develop during the $3^{\text {rd }}$ week with the $10-100 \%$ reduction of TC in column C-2.While in the column C-3 the biofilm layer was developed during the $6^{\text {th }}$ week of run with $25-96 \%$ reduction of TC

Mehran University Research Journal of Engineering \& Technology, Volume 36, No. 4, October, 2017 [p-ISSN: 0254-7821, e-ISSN: 2413-7219] 
concentration, as shown in Fig. 10. The high number of bacteria seemed to improve the adsorption mechanisms that enhance bacterial removal. Stevik et. al. [29] mentioned that the increase of bacteria (TC) concentration leads to improve the collisions between bacteria and media surface and subsequently increase the likelihood of the process within the media. The rate of adsorption increases linearly with the microbial concentrations. Stevenson et. al. [30] examined the transport and retention behavior of microorganisms through porous media, the results suggests that indicators of specific pathogens are not solely based on similar size, morphology and or surface charge but may be dependent on site-specific conditions where the other factors are involved during the process.

\section{CONCLUSION}

The canal-bed sediments contain fine clay, sand-silt deposits and the appreciable concentration of particulate organic matter that may enhance the growth of microorganisms to develop the biofilm layer over the bed, which can also reduce the hydraulic conductivity of the canal-bed to percolate the surface water into the aquifer.

The reduction in turbidity units by using the different quality of the influent water through the different grain size of the filter-bed in the columns have positive removal effect, the turbidity was reduced during the first week and further reduced during the column run for eight weeks. The clean filter-bed in the columns have developed the biofilm layer during the third week and started the removal of the TC concentrations, the Coliforms removal percent was increased up to $100 \%$ in the column C-2, containing $\mathrm{D}_{10} 0.1 \mathrm{~mm}$ grain size with undiluted canal water passed through the column at flow rate $0.5-1.25 \mathrm{ml} / \mathrm{min}$. Low flow rate at the outlet increase the detention time within the filter-bed that enhance the removal percent of the water pollutants. The grain size of the sediments and the quality of influent water has a direct impact on the removal efficiency of the filter-bed for the removal of turbidity and TC from water.

\section{ACKNOWLEDGEMENT}

The authors are wishing to acknowledge Mehran University of Engineering \& Technology, Jamshoro, Sindh, Pakistan, for its support to carry out this research work.

\section{REFERENCES}

[1] WHO (World Health Organization), and UNICEF (The United Nations Children's Fund), "Progress on Sanitation and Drinking Water Update”, WHO and UNICEF Joint Monitoring Program for Water Supply and Sanitation, France, 2010.

[2] PCRWR (Pakistan Council of Research in Water Resources),’Water Quality Status”, 3 ${ }^{\text {rd }}$ Report 2003-2004, 2005.

[3] Pakistan; Strategic Country Environmental Assessment Report: Rising to the Challenges, May, 2006.

[4] WHO, "Guidelines for Drinking-Water Quality”, 4 ${ }^{\text {th }}$ Edition, Geneva, 2011.

[5] Maupin, M.A.,Kenny, J.F., Hutson, S.S., Lovelace, J.K., Barber, N.L., and Linsey, K.S., "Estimated Use of Water in the United States”, US Geological Survey Circular 1405, USGS, Reston, VA, 2014.

[6] UNWWAP (United Nations World Water Assessment Program), "World Water Development Report: Water for a Sustainable World”, UNESCO, 2015.

[7] Chittaranjan, R., Melin, G., and Linsky, R.B., "Riverbank Filtration: Improving Source-Water Quality”, Water Science \& Technology, Volume 43, Springer, Dordrecht, The Netherlands, 2003.

[8] Kazner, C., Wintgens, T., and Dillon, P., "Water Reclamation Technologies for Safe Managed Aquifer Recharge”, IWA Publishing, London, 2012.

[9] Borchardt, M.A., Bradbury, K.R., Gotkowitz, M.B., Cherry, J.A., and Parker, B.L., "Human Enteric Viruses in Groundwater from a Confined Bedrock Aquifer", Environmental Science \& Technology, Volume 41, pp. 6606-6612, 2007.

[10] Bradford, S.A., Morales, V.L., Zhang, W., Harvey, R.W., Packman, A.I., Mohanram, A., and Welty, C., "Transport and Fate of Microbial Pathogens in Agricultural Settings”, Critical Reviews in Environmental Science \& Technology, Volume 43, pp. 775-893, 2013. 
[11] Scott, A., Bradford, J.S., and Thomas,H., "Microbial Transport and Fate in the Subsurface Environment", Journal of Environmental Quality (Special Section), pp. 1333-1337, 2015.

[12] Kanarek, A., and Michail, M., "Groundwater Recharge with Municipal Effluent:Dan Region Reclamation Project, Israel”, Water Science \& Technology, Volume 34, No. 11, pp. 227-233, 1996.

[13] Vohla, C., Alas, R., Nurk, K., Baatz, S., andMander, U., "Dynamics of Phosphorus, Nitrogen and Carbon Removal in a Horizontal Subsurface Flow Constructed Wetland", Science of the Total Environment, Volume 380, Nos. 1-3, pp. 66-74, 2007.

[14] Greskowiak, J., Prommer, H., Massmann, G., Johnston, C., Nützmann, G., and Pekdeger, A., "The Impact of Variably Saturated Conditions on Hydrogeochemical Changes during Artificial Recharge of Groundwater", Applied Geochemistry, Volume 20, No. 7, pp. 1409-1426, 2005.

[15] Kretschmer, N., Ribbe, L., and Gaese, H., "Wastewater Reuse for Agriculture”, Technology Resource Management \& Development-Scientific Contributions for Sustainable Development, Volume 2, pp. 37-64, 2000 .

[16] Costan-Longares, A., Montemayor, M., Payan, A. Méndez, J., Jofre, J., Mujeriego, R., andLucena, F., "Microbial Indicators and Pathogens Removal, Relationships and Predictive Capabilities in Water Reclamation Facilities”, Water Research, Volume 42, No. 17, pp. 4439-4448, 2008.

[17] Hiscock, K.M., and Grischek, T., "Attenuation of Groundwater Pollution by Bank Filtration”, Journal of Hydrology, Volume 266, Nos. 3-4, pp. 139-144, 2002.

[18] ASTM D6913-04,"Standard Test Methods for ParticleSize Distribution (Gradation) of Soils Using Sieve Analysis”, ASTM International, West Conshohocken, PA, 2009.

[19] Hazen, A., "Some Physical Properties of Sand and Gravels”, Massachusetts State Board of Health”, 24 ${ }^{\text {th }}$ Annual Report, 1893.

[20] APHA, (American Public Health Association), "Standard Methods for the Examination of Water and Wastewater", 2012.
APHA, "Standard Methods for the Examination of Water and Wastewater", $20^{\text {th }}$ Edition, American Public Health Association, American Water Works Association, and Water Environment Federation, Washington, DC, 1998.

[22] US-EPA, Federal Register, "Long Term 2 Enhanced Surface Water Treatment Rule”, Environmental Protection Agency Rules and Regulations, Volume 71, No. 3, pp. 654-786, 2006.

[23] Ray, C., Grischek, T., Schubert, J., Wang, J.Z., and Speth, T.F., “A Perspective of Riverbank Filtration”, Journal of American Water Works Association, Volume 94, No. 4, pp. 149-160, 2002.

[24] Alexandra, A.G., Katy, A.H., and Kerry, T.B.M.,”River Sediment and Flow Characteristics Near a Bank Filtration Water Supply: Implications For Riverbank Clogging”, Journal of Hydrology, Volume 344, Nos. 1-2, pp. 55-69, 2007.

[25] Hubbs, S.A., "Evaluation Streambed Forces Impacting the Capacity of Riverbed Filtration Systems", Chapter2, Hubbs, S.A., and NATO,”Public Diplomacy Division, Riverbank Filtration Hydrology Dordrecht, Great Britain, Springer, 2006.

[26] Ausland, G., Stevik, T.K.,Hanssen, J.F., Kohler, J.C.P.D., "Intermittent Filtration of Wastewater-Removal of Fecal Coliforms and Fecal Streptococci”, Water Research, Volume 36, pp. 2507-3516, 2002.

[27] Langenbach, K., Kuschk, P., Horn, H.M., "Slow Sand Filtration of Secondary Clarifier Effluent for Wastewater Reuse”, Environmental Science \& Technology, Volume 43, pp. 5896-5901, 2009.

[28] Stevik, T.K., Aa, K., and Hanssen, J.F., "Retention and Removal of Pathogenic Bacteria in Wastewater Percolating through Porous Media: AReview”, Water Research, Volume 38, pp. 1355-1367, 2004.

[29] Ekha, Y., Stephan, F., and Ursula, O., "Study of Slow Sand Filtration in Removing Total Coliforms and E.Coli”, JurnalSainsdanTeknologiLingkungan, Volume 6, No. 2, pp. 107-116, 2014.

[30] Stevenson, M.E., Sommer, R., Lindner, G., Farnleitner, A.H., Toze, S., Kirschner, A.K.T., Blaschke, A.P., and Sidhu, J.P.S.,"Attachment and Detachment behavior of Human Adenovirus and Surrogates in Fine Granular Limestone Aquifer Material”, Journal of Environment Quality, Volume 44, No. 5, pp. 1392-1401, 2015. 